\title{
Naturaleza and citizenship in Modern Spain. From subject representation to the dawn of contemporary citizenship (17th-19th centuries)
}

DOI

http://dx.doi.org/10.1590/2236-463320151106

Fabricio Gabriel Salvatto

Universidad Nacional de La Plata CONICET, Argentina

María Inés Carzolio

Universidad Nacional de La Plata CONICET, Argentina

\begin{abstract}
The Constitution of Cadiz of 1812 defines the profiles of the spanish subject and spanish citizen, to ones a clearly modern citizen, to others, a still immersed subject in the corporate world of the Ancient Regime. Is still debated, therefore, if the gaditana constitution has the aspects of the modern citizenship or if it drags the conditions of the former local nature which tends to become universal in the Hispanic Empire. From the proposed Great Memorial of the Conde-Duque de Olivares and the Nueva Planta decrees of Felipe $V$, We intend to review the main questions which appears crystallized in the Novisima Recopilación, then discussed in the Cortes doceañistas. There the terms nature and citizenship played a central role in the discussions, as well as later uses of corporate conceptions.

\section{Resumo}

A Constituição de Cádis de 1812 definiu os perfis do espanhol e do cidadão espanhol, para uns claramente como um cidadão moderno, para outros, como ainda imerso no âmbito corporativo do Antigo Regime. Se debate ainda, por conseguinte, se a Constituição gaditana tem os critérios que distinguem a cidadania modernas ou se traz a seu reboque a antiga natureza que tende a universalizar-se no Império espanhol. A partir da proposta do Gran Memorial do Conde Duque de Olivares e dos decretos da Nueva Planta de Felipe $V$, pretende-se avaliar as principais questões cristalizados na Novissima Recopilación, que foram logo discutidas nas Cortes gaditanas. Ai os termos natureza e cidadania tiveram um espaço central nas discussões, bem como empregos tardios de concepções corporativas.
\end{abstract}

\section{Keywords}

Constitution of Cadiz of 1812; Citizenship; Nature

Palavras-chave

Constituição de Cádiz de 1812; Cidadania; Natureza 
1

GARRIGA, Carlos. "Orden jurídico y poder político en el Antiguo Régimen", in GARRIGA, Carlos and LORENTE, Marta, Cádiz, 1812. La Constitución jurisdiccional: Centro de Estudios Políticos y Constitucionales, Madrid, 2007, pp. 43-72. In general, those authors who share this non-Statist conception of modern monarchies are labelled 'jurisdictionalists', whereas those who consider them States are called 'statists'. To each group, a characteristic paradigm is adscribed.

2

HESPANHA, Antonio. Visperas del Leviatán. Instituciones y poder político (Portugal, siglo XVIII), Madrid: Taurus, 1989, pp. 19-33. In turn, CLAVERO, Bartolomé. "Debates historiográficos en la historia de las instituciones políticas", in MONTANARI, Massimo; FERNÁNDEZ DE PINEDO, Emiliano; DUMOULIN, Michel et al, Problemas actuales de la historia. Salamanca: Ediciones de la Universidad de Salamanca, 1993, ps. 199-210), when referring to Hespanha's interpretation, posit that in it, regards the Old Regime 'in the Modern age, there is not a true political institution, but a "jurisdictionalist anthropology"' (p. 203).

3

GARRIGA, Carlos. "Orden jurídico " in GARRIGA, C. and LORENTE, M., op. cit., pp. 59-72.

On the historiographical alternatives of the topic, a tight summary with a complete and assessed bibliography can be found in FERNÁNDEZ SEBASTIÁN, Javier, "Cádiz y el primer liberalismo español. Sinopsis historiográfica y reflexiones sobre el bicentenario" in ALVAREZ JUNCO, José, and MORENO LUZÓN, Javier, La Constitución de Cádiz: historiografía y conmemoración. Homenaje a Francisco Tomás y Valiente. Madrid: C. E. P. y C, 2006, pp. 23-58. Also in MATURANA, Antonio Calvo and GONZÁLEZ FUERTES, Manuel Amador, "Monarquia, Nación y Guerra de Independencia: debe y haber historiográfico en torno a 1808", Cuadernos de Historia Moderna. Anejos, VII (2008), pp. 321-377, especially p. 354 ff.

5

ARTOLA, Miguel, Los Orígenes de la España contemporánea, 2 vol. Madrid: Centro de Estudios Políticos y Constitucionales, 1959, re-ed. 1975-1976. Other important titles on the Spanish nineteenth-century liberalism, among many others by the same author, are El modelo constitucional español del siglo XIX, Fundación Juan March, 1979, Nación y Estado en la España liberal, Madrid, Nóesis, 1994, La España de Fernando VII: la guerra de la Independencia y los orígenes del régimen constitucional, EspasaCalpe, S.A., 1999, La España de Fernando VII. Madrid: Espasa-Calpe, S.A., 1999, (ed.) Las Cortes de Cádiz Marcial Pons, Ediciones de Historia, S.A., 2003, Constitucionalismo en la historia, Barcelona, Crítica, 2005, La Guerra de la Independencia. Madrid: Espasa Calpe, 2008.
Introduction

For some historians, citizenship in the Cadiz Constitution is as revolutionary as the constitution itself. For others, constitution is modelled on a corporate conception based on the Old Regime and finds its antecedents in the figures of the natural subject and the vecino. It is necessary to acknowledge the fact that, among constitutions, there are irreducible differences arising from their belonging to different political cultures. Bearing this in mind, in the present article those conceptions of citizenship propounded by Peninsular and American deputies in the Cadiz Courts will be examined, as they link to two broader issues which are, on the one hand, the creation of modern citizenship, and on the other, American participation in its formulation.

When trying to show these issues in the adopted perspective, another equally significant problem is added: the question of historiographical operations and their incidence on the historical construction of this process, the recognition of some actors rather than others, the breaks and continuities in the coinage of fundamental concepts, etcetera. In order to observe these contrasting points we will study the historiographical problems related to the approach to Spanish nature and citizenship between the 17th and 19th centuries, revising those concepts and viewpoints on the political process in that period. This assessment will allow us to relate them to our approach to subject and citizen representation in the Old Regime problem, and its projection on the Cadiz debates.

The problem of citizenship, modern state and constitution in historiography The National State political power issue 1 is a concept whose crisis has led at the start of contemporary times to a need for definition as to whether centralized power in absolutist monarchies meant a functional antecedent for States. ${ }^{2}$ For many influential researchers today, 19th-century liberalism has achieved a legitimation structure of political domination by means of the invention of national historiographical and juridical-political tradition. This demanded an ideological operation by which history took on the task of naturalizing the idea of State, constructing State in the past as a political form characteristic of the socially organized man. If legal order in the present was configured from the dichotomy public-private as two poles in permanent contradiction, it was also projected towards the past, and the pre-contemporary world. Therefore, in order to understand the political dimension of the Old Regime it will be necessary to recover the keys to the juridical-political universe of the period; i.e., the jurisdictional culture and its institutional devices. ${ }^{3}$

Characterizing the Twelfth-Year Constitution has not been an easy task for historians of both groups, an issue that originates in efforts carried out in order to stress the benefits of a new political form of liberal tendency by a considerable portion of the Courts deputies, who sought to affirm Nation and Constitution roots in Spain's remote medieval origins which they aimed at recovering and making current. This political use of the past was consolidated in a traditional interpretation which resounded in medievalists and modernists until the first half of the 20th century ${ }^{4}$. The identification of the 1812 Cadiz Constitution with the expression of a bourgeois revolution started with Miguel Artola ${ }^{5}$, who found the origins of contemporary Spain in the Cadiz Courts and the Constitution, with printing freedom and separation of powers, which he celebrates as 'a huge revo- 
ARTOLA, Miguel. Los Orígenes, vol. I, p. 9. Also in ARTOLA, Miguel. (ed), Las Cortes de Cádiz, with contributions by Morán Ortí, M. R. Flaquer Montequi, J. I. Marcuello Benedicto, A. Gallego Anabitarte, M. Pérez Ledesma, J. Ferrando Badía.

7

ARTOLA, Miguel. Los Orígenes, vol. I, p. 117

See CALVO MATURANA A. and M. GONZÁLEZ FUERTES Amador, op. cit., pp. 355-356. There is a mention of the influence of FURET, François (Pensar la Revolución Francesa, Madrid: Petrel, 1980). Also in PASAMAR, Gonzalo. "Medio siglo de historiografía: la escuela de los Annales en España", III Jornadas de Historia Moderna y Contemporánea (Sept. 15-17, 2004) UNdeINE, F. de H., Dep. de Historia, R. Argentina 2004 (CD).

9

SUÁREZ, Federico, La crisis política del Antiguo Régimen en España (1800-1840), Madrid: Rialp, 1950, Las Cortes de Cádiz, Madrid: Rialp, 1982, among other works.

10

TOMÁS Y VALIENTE, Francisco. "Génesis de la Constitución de 1812. I. De muchas Leyes Fundamentales a una sola Constitución", Anuario de Historia del Derecho Español, T. LXV, 1995, pp. 13-125.

11

Ibidem, p. 101. Bartolomé Clavero had already published "Política de un problema: la Revolución burguesa", in CLAVERO, B., RUIZ TORRES, P. and HERNÁNDEZ MONTALBÁN, F. J., Estudios sobre la Revolución burguesa en España. Madrid: Siglo XXI, 1979, pp. 1-48, pointing out the legal revolution arising from the bourgeois revolution, started in 1808, but successful in 1836. It had been preceded by the article "Para un concepto de revolución burguesa", Sistema. № 13 (1976), pp. 35-54. On the political use and sharp critical assessment of publications done in the event of the date, as well as criticism of the use of the nation concept in the 1978 constitution, "Cádiz en España: signo constitucional, balance historiográfico, saldo ciudadano", en GARRIGA, Carlos and LORENTE, Marta, Cádiz, 1812. La Constitución jurisdiccional. Madrid: Centro de Estudios Constitucionales, 2007, pp. 447-526.

12

CLAVERO, Bartolomé. "Tomás y Valiente insólito", Claves de razón práctica, № 72 (1997), pp. 41-48, apud J. FERNÁNDEZ SEBASTIÁN, op. cit. p. 35.

13

PORTILLO, José M. Revolución de Nación. Orígenes de la cultura constitucional en España, 1780-1812, Madrid: CEPC, 2000, pp. 20-22. 'When introducing Agustín de Argüelles's historical examination of the constitutional reformation in Spain, Artola presents a compact period between 1808 and 1812, which responds to the start of an Old Regime Crisis, goes through a moment of Convention revolutionary government and arrives at a parliamentary monarchy and a society change', which assimilates the Spanish war to the identity signs of the European (French) revolution. The title of the former was inspired by the passage from the category of Catholic monarchy to Catholic nation, lutionary effort to provide the country with a new structure.' ${ }^{\text {The nation }}$ which would only emerge from the 'complete break with persons and institutions representative of the Old Regime'7 is the protagonist of what Artola calls a 'national uprising' by which the Provincial Juntas take on sovereignty in the absence of the king, as a result of the clash with French authorities. The interpretation of this movement by Artola and his followers, both in its popular origins and its spontaneity or the revolutionary conscience with inspires it, has been questioned in the past few years. ${ }^{8}$ This assessment gave rise to controversy faced with the conservative viewpoint of Federico Suárez ${ }^{9}$ and his group, who tended to see in the Twelfth-Year Constitution a version of the 1791 French Constitution.

Francisco Tomás y Valiente, who started from positions close to Miguel Artola's as regards liberalism in the 70s, published since his reinstatement in research several works on constitutional topics from the history of Law, with a parallel orientation to that of other researchers such as José Portillo Valdés, Bartolomé Clavero, Joaquín Varela Suanzes-Carpegna, Ignacio Fernández Sarasola; and started a new line of analysis which his followers would continue along in the 90 s. ${ }^{10}$ Tomás y Valiente takes a methodological position which emphasizes the 'juridical-political culture' of the enlightened and the Twelfth-Year Constitution. In a founding article, he critically reviews the postures stated by Artola and Suárez, positing and contextualizing the contradictory doctrinal viewpoints of those who participated in the constitutional process and the final drafting of a unique, uniform new Constitution ${ }^{11}$, where a new agent appears: the Nation. There is a change of attitude regards prior sociological interpretations, but also the focus is displaced from social and economic structures to the study of the individual and his rights. ${ }^{12}$

In turn, Portillo criticises Artola's model on the Old Regime crisis in Spain saying that it leads unhesitatingly from 1808, through a revolutionary government, to a parliamentary government and society change, leaving aside other alternatives coming from a traditional order. As he declares himself, it is interesting for him to study how the passage from Catholic monarchy to Catholic nation, and the arrival to the 'strong national content of the revolution', happen. ${ }^{13}$

The nation would constitute the core of the Cadiz debates, which would find a strong obstacle in the problem of pre-existing nations, peoples, and political bodies in las Españas (the several Spains) ${ }^{14}$, a capital topic in the works of the cited historians. But also, as it is widely known, deputies showed different doctrinal affiliations and, therefore, held different concepts of nation as deriving from traditional (dualist) or liberal (nation as unitary and sovereign subject formed by the whole of the Spanish) pactist conceptions, which in turn led to different modes of representation (stratified and organicist, the former; the citizens', the latter). ${ }^{15}$

Clara Álvarez Alonso states that the new order launched by the end of the 18th century in France and the United States implied the change of an empirical to a normative concept of Old Regime constitution. However, the empirical, i.e. pre-revolutionary, Constitution does not disappear with the normative Constitution: it remains a 'constitutional reality'16. Thus, in new political formations, there was what she calls a factual constitution which reproduced social reality, identified with the empirical one and co-existing with the normative or legal one. The pre-condition for the normative constitution to succeed is the assured rights guarantee and a 
used by Pablo Fernández Albaladejo (Fragmentos de Monarquía, Alianza, Madrid, 1992), as pointed out in the "Introducción General" in the former, p. 21. Besides the aformentioned, see, by the same author, "De la Monarquía Católica a la Nación de los Católicos", Historia y Política: Ideas, procesos y movimientos sociales, 17 (2007). Among his latest publications J. M. Portillo, Crisis Atlántica. Autonomía e Independencia en la crisis de la monarquía hispana, Madrid, Marcial Pons-Fundación Carolina, 2006.

14

FERNÁNDEZ SEBASTIÁN, in J. ALVAREZ JUNCO and J. MORENO LUZÓN, op. cit., p. 36. The topic has also been discussed in CLAVERO, Bartolomé, PORTILLO, José M. and LORENTE, Marta, Pueblos, Nación, Constitución (en torno a 1812), Ikusager ediciones S.A. and Fundación para la Libertad, Vitoria-Gasteiz, 2004.

\section{5}

VARELA SUANZES CARPEGNA, Joaquín. op. cit., ch. 4 and 5. Due to methodological considerations, Suanzes Carpegna attributes to the manifestations of these positions a clarity with which we do not agree. It should be enough to remember that there is still no liberal party with a uniform ideology.

16

GRIMM, DANIEL. "The Constitution in the process of the Nationalization", Constellation, XII, Dec. 4. 2005, pp. 447 ff, apud ÁLVAREZ ALONSO, Clara, "El abandono de la edad de la tutela? Algunas cuestiones sobre el constitucionalismo revolucionario", in ALVAREZ JUNCO, J., and MORENO LUZÓN, J., op. cit.pp.

59-74. According to the former, the constitution always goes with the form of State in its formation process, whose origins reach early modernity, a period in which the fundamental laws are formulated for the first time (ibidem, pp. 64-65).

17

Ibidem, pp. 65-66. See also the observations by VALLEJO, Jesús, "De sagrado arcano a constitución esencial. Identificación histórica del derecho patrio" in FERNÁNDEZ ALBALADEJO, Pablo. (ed.), Los Borbones. Dinastía y memoria de Nación en la España del siglo XVIII, Madrid: Marcial Pons-Casa de Velázquez, 2001, pp. 423-484.

18

FERNÁNDEZ ALBALADEJO, Pablo. "Dinastía y comunidad política. El momento de la patria" in FERNÁNDEZ ALBALADEJO, Pablo (ed.), Los Borbones..., Madrid: Marcial Pons-Casa de Velázquez, 2001, pp. 485-532, and in Materia de España. Cultura política e identidad en la España moderna, Marcial Pons, Madrid, 2007, pp. 197244. Ibidem, p. 234 notes that the Jesuit Burriel felt allowed to state that 'there could not be "any more Nationality nor naturaleza than the Spaniards' general one"'.

19

ÁLVAREZ ALONSO, Clara, op cit.,pp 65-66.

20

TOMÁS Y VALIENTE, Francisco. "Génesis..." op. cit p. 15; VARELA SUANZES CARPEGNA, J., classifies them into realists, Americans, liberal; even if their attitudes regards the debated issues are softened. definition of separation of powers. Even though the Bourbon government started to advance in that direction in the 18th century and Enlightened political writers tried to establish new grounds for monarchy, legislation, a product of the sovereign power, could not go beyond the limit constituted by corporations and their theoretical basis. ${ }^{17}$ It cannot be stated, however, that nothing changed under the Bourbons. Pablo Fernández Albaladejo has reflected deeply on the propositions put forth by the enlightened writers and their new attitude towards external and internal politics, as well as their historiographical search for legitimation. ${ }^{18}$ Still, not only was there no theoretical advance towards a Nation of individuals, but, as Álvarez Alonso affirms, the concept of sovereignty was not defined either, or made into a unique, indivisible reference, and above all, it was not possible to justify the power concentration implied by overcoming its transcendental legitimation to become the immanent general will. ${ }^{19}$

The Cadiz Courts, at troubled times both in Europe and America, experienced inner conflict in a debate that involved juridical-political cultures of diverse orientations: 'radical, reformist, Gallicised and absolutist liberals ${ }^{20}$, who in general disguised the origin of their political ideas in view of the war situation, preferred to refer to some 'fundamental laws', 'our old institutions' or 'our old Constitution', which were interpreted differently in each case. All those expressions shared a mythicization due to the prestige of the idea of an English or British Constitution in the second half of the 18th century when, in addition, E. Burke's version of a traditional Constitution with medieval origins had taken root. ${ }^{21}$ This is the version of historical Constitution preferred by the moderate and reformist Spaniards at the time. Both the enlightened and the liberals mentioned fundamental laws and Constitution. They were useful to set the grounds for the former. They posited that, even though Spain had had both, they had been destroyed by despotic governments, or forgotten, and in order to recover them they had to be rebuilt. But what were they? There were kingdoms and provinces that had had them and repealed them, but that was not always the case. During the 18th century, several sparse dissidence manifestations appear where an uncontested absolutism is presumed to have been found. ${ }^{22}$ But there were also constitution proposals based on different principles, since they were defended by 'Province political bodies' with corporate, stratified societies. ${ }^{23}$ The problem was, then, to make compatible what was general or common and what was particular or specific, between historical constitutions and fundamental rights of some Hispanic territories, and the ordering of Spain as a nation at a constituent moment. How should it be imposed? Some defended drastic means, others, a softer approach. ${ }^{24}$ We also find in the debate several concepts of nation: the traditional corporate Old Regime society of naturales or subjects, the enlightened Spanish patriotic or nationalist nation which will tend to coincide with 'people', the sovereign nation made up of free, equal and independent individuals and the Romantic essentialist. ${ }^{25}$ The concept of 'nation' frames that of national citizenship, as it constitutes the collective body in which sovereignty resided, and it is necessary to have nationality in order to enjoy citizenship. ${ }^{26}$ The citizenship debate in a Spain which starts its revolutionary process in 1808 came from a political culture that was different from the French one, and conditioned by the conflict with France.

Covarrubias's concept of 'citizen' had changed in the enlightened discourse and their very conception of their power, even though it was 
TOMÁS Y VALIENTE, Francisco. "Génesis " op. cit. pp. 17-26. Against the authoritarian Hobbesian version which made fundamental laws a real and unappealable faculty, another, more traditional, line regards them as kingdom and not king's laws, which the king himself cannot repeal and must comply with by the contract by which he is limited. In Tomás y Valiente's opinion, the history of English constitutionalism consists of a contrast between the king's superiority and the common law's, as far as the latter is a repository of legal, custom and judiciary precedent. In the 18th century this position had succedeed, as well as the Parliament superiority over the Crown, which supported the idea of England's own Constitution shared by the 'moderate', Jovellanos being one of them. On this basis of the fundamental limiting laws having lost relevance when inscribed in a greater whole, in the second half of the 18th century, with Montesquieu, Blackstone, De Lolme and others, the prestige of an English Constitution is built: non-Republican and a work of history, but with a balance of powers. But the E. Burke version of the historical continuity myth of a constitution that incarnated a tradition reaching back to at least the 13th century an idea which was opposed to revolutionary elaborations- would have, according to Tomás y Valiente, a deep influence on 'Spaniards who were sensible to the ideas of tradition, fidelity to history and pragmatism.

22

FERNÁNDEZ ALBALADEJO, Pablo. "La Monarquía de los Borbones", in Fragmentos de Monarquía. Madrid: Alianza, 1992, pp. 353-454. TOMÁS Y VALIENTE, op. cit., pp. 40-42, mentions several studies along the same lines.

23

TOMÁS Y VALIENTE, "Génesis...", op. cit., pp. 42-51, concludes that 'the plural historical constitution of the Hispanic Monarchy during the Bourbon century had not been forgotten, presented under the topic of a unifying and homogenizing century.'

24

Ibidem, pp. 51-56.

25

FERNÁNDEZ SEBASTIAN, Javier, "España,

monarquía y nación. Cuatro concepciones de la comunidad política española entre el Antiguo Régimen y la Revolución liberal, Studia Historica, Historia Contemporánea, vol. XII (1994), pp. 45-74.

26

PÉREZ LEDESMA Manuel, "La invención de la ciudadanía moderna" in PÉREZ LEDESMA, Manuel (dir.). De súbditos a ciudadanos. Una historia de la ciudadanía en España. Madrid: CEPC. 2007, pp. 35-36. The French 1791 constitution 'explained for the first time who were to be considered "French citizens"': concretely, 'those born in France of a French parent; those born in France of a foreign parent who has settled in the kingdom; those born abroad, descending in any degree from a Frenchman or woman who has been expatriated due to religious reasons, who settle in France and swear the civic oath.' (Tit. II, art. 2). Also those foreigners who had resided continuously in French territory for over five years could aspire to the same condition as long as they had also still the one registered in the Diccionario de Autoridades, 'the town vecino (neighbour) who enjoys its privileges and is bound to its charges, not being relieved of them by any particular exemption.'27 The passage from aggregated monarchy to that sketched by the Nueva Planta tended to reduce the political space as an exclusive jurisdictional environment of the agents of Royal power, at the expense of their own rights recognition. The new territorial structure would tend to be modelled on provinces, not kingdoms, but successive Nueva Planta decrees by Philip V himself would lead to a progressively moderate tone which, though acknowledging limits that circumscribed his absolute power, assumed the traditional jurisdictionalist conception of power. ${ }^{28}$ Even if the Hispanic monarchy becomes the kingdom of Spain, Fernández Albaladejo states that there is no reason to see in this a process that can be equated with the 'modern power state', since power rationalization and concentration phenomena were also registered in the past, and he considers that their dynastic patrimonial component cannot be ignored. ${ }^{29} \mathrm{His}$ successor, Ferdinand $\mathrm{VI}$-and his minister Ensenada- would continue along an interventionist line of action which 'implied accepting the definitive deferral of jurisdictionalist monarchy as a principle. ${ }^{30}$ The same political tendency was adopted by Charles III. ${ }^{31}$ But most conflicts recorded in municipalities due to the power of local oligarchies required a new construction of the relations of these oligarchies with the monarchy. ${ }^{32}$ The mutiny against Esquilache, caused by the grain tax exemption and the edict against cloaks and hats triggered a popular reaction to the benefit of a complex network of interests corresponding to a fierce fight over municipal resources. The riots awoke a strong reaction in Charles III, who responded with dispositions which strengthened the corporate constitution of the kingdom. By the decree passed on May 5th, 1766, the annual election of four representatives named by the common in neighbourhoods or parishes in every town in the kingdom, and a trustee solicitor who would act as a public personero (attorney for the people). ${ }^{33}$ Electors would be those 'taxpaying laypeople (vecinos)' who would designate delegates, who would then in turn choose deputies for an annual and later biennial period. This creation, which sought to introduce 'commoners' in municipalities, was part of an enlightened program and tried to commit them to the town supply management, but, as Antonio Dominguez Ortiz interpreted, they could not awake as much interest as it was hoped in likely addressees, due to policy inefficacy and deep social prejudice. ${ }^{34}$ At other times, the simulated democratic content of the decrees has been questioned, which he himself refuted. Dominguez Ortiz recalls that what urban oligarchies rejected was participation of vassals as such in government, not town, tasks, and they did not object the elective system that since earlier centuries had been enforced in the popular designation of town jurors and town council meetings in small towns. The mention of taxpayers does not imply a census vote, which was not in practice, but the kind of universal male suffrage of the vecinos which, he estimates, was the norm in deputy elections in the Cadiz Courts. ${ }^{35}$ What was achieved through the reformation was a greater control of municipal funds by the central Administration, even if the aspiration was to enlarge popular representation in some oligarchic bodies. Results were modest, as a radical renovation was impossible in the 18th century and as suppression of privatized posts - in practice, enlarged by the attraction exerted by 'the powerful' could only be achieved by revolutionary means or indemnification of those 
purchased real estate, or married a Frenchwoman, or created an agricultural or commercial venture, and sworn the civic oath (art. 3 and 5).

27

Diccionario de Autoridades. RAE online. 'Ciudadano' (citizen).

28

On the application of the Nueva Planta and modifications, institutional Castilianization, and Charles III reforms, see FERNÁNDEZ ALBALADEJ0, P. "La monarquía de los Borbones", in Fragmentos..., op. cit. pp. 353-454.

29

FERNÁNDEZ ALBALADEJO, P. "La monarquía ", in Fragmentos..., pp. 382 ff, especially pp. 395, 400, 402. Likewise, GONZÁLEZ ALONSO, Benjamín, "El régimen municipal y sus reformas en el siglo XVIII", in Sobre el Estado y la Administración de la Corona de Castilla en el Antiguo Régimen. Madrid: Siglo XXI de España Editores, S. a., 1981, p. 201, recalls that in the 18th century, the state reformation connotes a 'persistent regulatory attitude' leading to a 'rigorous administrative centralization' of 'centralizing leaning'; as Tocqueville observes, centralization was not 'a Revolutionary conquest, but on the contrary, a product of the Old Regime.'

30

FERNÁNDEZ ALBALADEJO, P. "La monarquia ", in Fragmentos..., p. 408

31

See FERNÁNDEZ ALBALADEJO, Pablo. "La monarquia ", in Fragmentos..., pp. 412 ff. The "Memorial de Greuges de 1760", p. 414, note 192,415 , note 196 . The author alludes to the opinion of J.-M. Palop, "Centralismo borbónico y reivindicaciones políticas en la Valencia del setecientos", Homenaje a Juan Reglá, Valencia, 1975, II, pp. 65-77, who regarded that memorial as 'a plea for perfecting the nueva planta'. Mainly, it denounces the 'decay of municipal life following the expropriation of competences carried out by the nueva planta' and the 'totally Castilianist leaning with which the office distribution had been practised... in monarchy as a whole.' In the last point, there is a reference to the possibility for coexistence between monarchic authority and oligarchies, and that in diverse regions with different laws the naturales would govern their kingdoms, subordinated to the sovereign's supreme authority.

32

FERNÁNDEZ ALBALADEJO, P. "La monarquia ", in Fragmentos..., p. 420-421, though he warns that not all conflicts are produced by the advance of Bourbon centralism. Conflicts caused by oligarchic interests due to tax registration, patrimonialization of public offices that hindered all other participation, were understandable in the context of a jurisdictionalist monarchy.

33

lbidem, pp. $437 \mathrm{ff}$

DOMÍNGUEZ ORTIZ, Antonio. "Un intento de reforma municipal", in Sociedad y Estado en el siglo XVIII español. Barcelona: Ariel, 1981, pp. 454-475, "Política interior y exterior", in Carlos IIl y la España de la Ilustración. Madrid: Alianza, affected (infeasible during Charles III's reign). In turn, Fernández Albaladejo notes that the treatment accorded to diputados (deputies) and personeros (attorneys), as to the rest of the municipal corporation members, was only used for the latter as long as they constituted a 'community body'; but, outside it, 'each of them only enjoys the treatment due to them by rights of birth, dignity or prerogative. ${ }^{36}$

A balance of these discussions allows us to reach certain central issues in our topic. With this legislation, Bourbon monarchy had reached the constitutional limits of the corporate system. The Royal constitution is imposed not without trouble, as concepts in force in the Old Regime will remain in debates and legislation. Yet the Cadiz Courts Deputy Agustín de Argüelles testifies to the remaining lack of definition when he states that 'The word citizen cannot still be understood in the vague, undetermined sense it has had so far. Though an old term, with the Constitution it has acquired a certain, precise, exact meaning. It is new in legal nomenclature and cannot be confused hereafter with the word vecino. ${ }^{137}$ As we have seen before, already during the second half of the 18th century there were attempts to increase participation of the vecinos in town council offices, albeit with negative effects.

\section{Definition of naturaleza in the Nueva Recopilación. Proposal by Olivares and Philip V.}

To revise the truth in this statement, it will be convenient to observe which are the Old Regime elements detected in the scene of pre-constitutional debates and what has been called 'Royal constitution'.

During the late Hapsburg dynasty, enjoyment of vecindad and $n a-$ turaleza (nativeness) meant, for vecinos and subjects, enjoying exclusive privileges but also obligations, from which mere residents and outsiders ${ }^{38}$, as well as foreigners, were excluded. Vecindad and naturaleza had similar conditions in ordinance compilations and collections, connected with a double link with culture and political forms. By the 17th century, vecindad and naturaleza already had a long history. In the Early Middle Ages there was in the peninsula both a political and a normative dispersion which, due to population mobility during the Muslim-Christian dispute, converted residence in a fundamental requisite to achieve the condition of vecino. For such a recognition, residence in a town with municipal term recognized by the Crown or its officials was necessary; also, that the townsperson residence was lasting ${ }^{39}$, that it was based on a supposition of stable living (i.e., with house and homestead in the same town, material links), that the townsperson was acknowledged as a member of the local community, and that he shared an identity as such against out-of-towners because of his participation in cultural values and his expression of its juridical consistence as an autonomous political community. ${ }^{40}$

From the 14th-15th centuries onwards a strengthening of kingdom central administration in detriment of local entities took place, which progressively see their competences expropriated. The kingdom will be constituted by the figure of the natural, which will tend to consolidate over the vecino, limited to the local sphere.

In the 16th century, with juridical technique progress, the formulation of naturaleza will emerge; not only based on material linking or residence criteria, but also based on the born at... and descended from... parameters, referring to formal and cultural elements of the kingdoms which 
1990 (1988), pp. 95-114, especially 101-107. In the latter work, Dominguez Ortiz quotes GUILLAMÓN J., Las reformas a de la administración local durante el reinado de Carlos III, Madrid: IEAL, 1980, con ejemplos de Oviedo, Badajoz, Alcalá y Albaicín, confirming the same results. Other cases: BARBA, Jesús Marina. "La reforma municipal de Carlos III en Ciudad Real (1766-1780)", Chronica Nova 14, 1984-85, pp. 249-291; GÓMEZ MARTíNEZ, Alfredo. "Cargos y oficios municipales en las ciudadres de León, Zamora y Salamanca durante el reinado de Carlos III, Estudios humanísticos. Historia, $\mathrm{N}^{\circ} 5$, 2006, pp. 159-184.

35

DOMíngueZ ORTIZ, Antonio. "Política ", Carlos IIl y la España de la Ilustración, Alianza, Madrid, p. 105. This emphasizes the absence of a traditional division between men of noble birth and commoners reflected in the mitad de oficios, as a symptom of estate society weakening.

36

FERNÁNDEZ ALBALADEJO, P. "La monarquía ", in Fragmentos..., p. 440. For this researcher, both the 'municipal reform' and the 'co-regimental reform' following it 'illustrate well the difficulty of simply identifying the process of corporate re-composition with that of an incipient statalization of the political order' (p. 450).

37

Diario de Sesiones de las Cortes Generales y Extraordinarias. Biblioteca virtual Miguel de Cervantes, 2005, 4 tomes, 1811, September 4th, 1811 Session, No 337, hereinafter DSCGE. See the next note for Argüelles's complete speech.

38

DSCGE, op. cit. Sept. 4th, 1811 Session, No 337, p. 1765. This is recalled by Argüelles against Guridi and Alcocer when, after uttering the words quoted above, he continues: 'It is new in legal nomenclature and cannot be confused hereafter with the word vecino. Even among us this meant more than what Mr. Alcocer has indicated in his erudite speech; since it not only enabled the vecino to be part of a guild, factory steward, etc. but also for municipal offices of great import, mayor, ordinary judge, alderman, deputy for the commons, etc. In other offices, the vecino can choose according to his merit with the rest of the Spaniards.'

39

According to the town needs (administrative, defensive, reproductive), the residence requisites could vary between one and ten years. In all cases, what was sought with this was to obtain identification with a local identity built on a common culture.

40

COSTA, Pietro, Civitas. Storia della citadinanza in Europa. 1. Della civiltá comunale al settecento, Laterza, Bari, 1999, ch. 1 "La cittadinanza medievale", pp. 3-50, especially sections 5, 6 y 10.

41

See next note.

42

"Aunque por leyes de estos Reynos está prevenido, que los que no fueren naturales de ellos no puedan tener Prelacias, Dignidades ni otros Beneficios; porque se ha dudado y duda integrated the new political formations. Thus, the son's naturaleza will be his parents' and their birthplace, if they have naturaleza there. The ius soli, which defined the municeps in the Late Empire (born from legitimate parents who belonged to the child's birthplace), was connected in feudal law with those born in a territory, who by that fact were subjected (subiecti) to the lord of the land (dominus terrae), whereby the idea of bounding those born in a certain geographical space to the power of a king. This was acknowledged in the Partidas, but not as the only criterion, since homestead and family constitution were also necessary (ius sanguini). In the Henry III Pragmática decree (1369) on the reserve of offices, benefits and ecclesiastical pensions for the naturales, the latter were defined as 'those who were true naturales from their mother and father lines, and born of them.41

Philip II would define in 1565 the Castilian naturales in a pragmática which compiles all these considerations. ${ }^{42}$ The definition inscribed in it is due to the need for differentiating in other regions of the empire those who were Castilian, and thus carried certain privileges, from those who were not. Herzog finds that this distinction was crucial in America, since kingdoms had appeared there which were added to the Castile crown and where Castilians monopolized offices and benefits as a result.. ${ }^{43}$ These conditions would be considered too restrictive not only by the naturales of other peninsular kingdoms but also by the monarchy itself, who was interested in the materialization of its dominions in the vast spread of the American continent, and finally decreed in 1620, under Philip III, that any foreigner's child who was born in Spain was to be considered as true, native and natural in the Indies. ${ }^{44}$

As we know, the acquisition of naturaleza, as of vecindad, were reversible and they could be lost by not fulfilling the condition of residence.

During the reign of Philip IV, in the 1624 Gran Memorial proposal, drafted under inspiration of Gaspar de Guzmán, Conde-Duque de Olivares, the king is urged to reduce the heterogeneous legislation specific to the peninsular kingdoms ${ }^{45}$ to the common denominator of the Castilian one: '... to establish and set the laws in conformity with the laws of Castile...' He would not succeed, but with the change of dynasty, the first Bourbon would renew the attempt through the Nueva Planta decree. ${ }^{46}$ Historiography has traditionally stressed the monarchy's intention of administrative modernization and the rationalistic criterion which inspires it, driven forward by the Bourbons. Even though the Nueva Planta decrees were especially oriented towards solving fiscal and administrative problems according to current practices in European monarchies ${ }^{47}$, the new dynasty strengthened inner unity. ${ }^{48}$ The application of the Nueva Planta, after the Succession War, caused that the more radical reforms were meant primarily for the rebel kingdoms, while political reasons allowed the allied kingdoms (Navarre, Basque Country) to retain their privileges. The decrees did not merely mean the disappearance of the particular naturaleza of the former.

The Bourbon French tradition was centralizing and the 1700 Catalan rebellion in the Succession War provided them with the motivation for intervention which allowed a tabula rasa of Catalan local privileges, but at the same time favoured the substitution of institutions which helped centralization, such as capitanías, intendencias and audiencias, for old autonomous bodies. ${ }^{49}$ From the first decrees in June and July 1707, the will for all Spanish kingdoms to be reduced to 'the uniformity of the

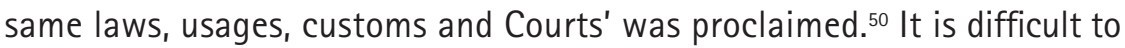


quales se dirán naturales, para poder los dichos Beneficios, ordenamos y mandamos, que aquel se diga natural, que fuera nacido en estos Reynos, e hijo de padre que ámbos á dos, ó á lo ménos el padre, sea asimismo nacido en estos Reynos, ó haya contraído domicilio en ellos, y demás de esto haya vivido en ellos por tiempo de diez años; con que si los padres, siendo ámbos, ó á lo menos el padre nacido y natural en estos Reynos, estando fuera de ellos en servicio nuestro, ó de paso, y sin contraer domicilio fuera de estos Reynos, hobieren algun hijo fuera de ellos, este tal sea habido por natural de estos Reynos..." ('Even though by the laws of these Kingdoms there is warning that those who are not native to them cannot have Prelacies, Dignities or other Benefits; because it was doubted in the past and is doubted still whether they are native, in order to access the said Benefits, we order and decree that he who calls himself native, who was born in these Kingdoms, and son of parents, or at least father, who was also born in these Kingdoms, or has settled down in them, and besides has lived in them for ten years; and if parents, either both of them, or at least the father, is born and native to these Kingdoms, being away from them in our service, or in passing, and without settling down outside of these Kingdoms, bear a child outside them, the child will be a native to these Kingdoms...'). Novisima Recopilación de las leyes de España Book I Title XIV Law VII. 1805.

43

HERZOG, Tamar. "Los americanos frente a la Monarquía. El criollismo y la naturaleza española", in ALVAREZ-OSSORIO ALVARIÑO, A. and GARCÍA GARCÍA B. J. (eds), La Monarquía de las naciones. Patria, nación y naturaleza en la Monarquía de España. Madrid: Fundación Carlos de Amberes, pp. 76-92, especially pp. 80-81.

44

Novísima Recopilación. Third Tome, Book IX, Tit. XXVII, San Lorenzo, July 14th, 1620.

\section{5}

'Consider it the most important affair of your monarchy to become king of Spain; I mean, Sir, for you not to be contented with being king of Portugal, or Aragon, of Valencia, count of Barcelona, but that you should work and think with mature and secret judgement about reducing these kingdoms which form Spain to the style and the laws of Castile...', in DIAZ PLAJA, Fernando, La Historia de España en sus documentos: El siglo XVII. Madrid: Instituto de Estudios Politicos, pp. 119-121.

46

FERNÁNDEZ ALBALADEJO, P. (ed.) LoS Borbones... p. 485

47

MARTÍNEZ SHAW, C. and ALFONSO MOLA, M., Felipe V. Madrid: Arlanza. 2001, p. 210, C., 2002 48

VILAR, Pierre. Historia de España. Barcelona: Crítica, 2008, p. 110.

49

VILAR, P., op. cit. p. 113.

50

FERNÁNDEZ ALBALADEJO, Pablo, "La Monarquia", Actas del Congreso Internacional ignore the transcendence of this policy, which breaks with the aggregationist configuration of Spanish monarchy, whereby each kingdom preserved its juridical-political identity, instead remodelling the whole according to the form of government of only one of its bodies: Castile. Besides, hereinafter there will be a tendency to speak of provinces and not of kingdoms.

From the late 16th century the Castilian monopoly in the Indies had been gradually opening to the naturales of other peninsular kingdoms. ${ }^{51}$ But Philip V aspired to a radical broadening of the scope: the acknowledgement of general naturaleza to all Spaniards. ${ }^{52}$ The Nueva planta de la Real Audiencia del Principado de Cataluña decree reiterates in several chapters this royal will:

'7. Being my intention to honour and award indiscriminately all my vassals, according to their merits, and employ them as I judge most convenient, I declare and command that hereafter cease in Mallorca $(b, 2)$ those customs and laws that speak of foreignness. ${ }^{53}$

'40. Foreignness prohibitions $(I, 5$.) must cease, since my Royal intention is that in my Realm dignities and honours be conferred $(m, 5$.) reciprocally to my vassals according to merit, not birthright, in any Province therein. ${ }^{54}$

Only ecclesiastical prebends ${ }^{55}$ and benefits are excluded, and it is established that 'In the option of Ecclesiastical offices and placements, those from Aragon, Valencia, and Catalonia be equal to those from Castile, leaving those from Majorca in possession of their Ecclesiastical annuities and exemptions, which they enjoy by Royal Decrees and Pontifical Bulls. ${ }^{56}$

\section{Late uses of naturaleza in the Novísima Recopilación}

Thus, this is a significant expansion of naturaleza. As observed in the first part of this article, the issue of political representation in the Cadiz charter and the constitutional debates shows a controversial character in historiography, especially for those historians who focus their studies in transformations from the first Spanish liberalism. At this level of discussion, Old Regime subject and vecino representations appear to enjoy less of a controversial status, since for that historiography the latter is characterized as a pre-constitutional stage and given to split substantially from the 19th century debates. However, for historians who work in the Late Medieval and Modern periods, this framework is not closed to debate. As pointed out above, continuities in Old Regime elements which were captured in the normative, as a result of heated discussions during 1811, invite closer observation of these historiographical elements on the topic and the analysis of current legislation in the 17th and 18th centuries.

Tamar Herzog has remarked several important points resulting from the new concept of nature implanted by the Nueva Planta; they are worth mentioning, as this not only involves the peninsular kingdoms, but also the New World's: ${ }^{57}$

1) Some historians believed that such implantation caused no trouble and that it only became difficult when illegal practices were involved.

2) Other historians took no notice of the fact that the fight for obtaining naturaleza for the colonial enterprise was not a nationalist struggle, since the category of naturales in Spain -also applicable in the Indies- was a juridical and social construction.

3) It was not a concern to study why some persons and not others were classified as naturales. 
"Carlos III y la llustración", Madrid, 1989, 3 vol. I, pp. 1-89, especially p. 2

51

HERZOG, Tamar. Vecinos y extranjeros. Hacerse español en la Edad Moderna. Madrid: Alianza, 2006, p. 108 and p. 307, note 4. Recopilación de Indias, Law 28, tit. 27, book 9 .

52

Tomo Tercero de Autos acordados, Madrid, 1745 Facsimile LEX NOVA, Valladolid, 1982.

53

"7. Siendo mi intención, honrar, i premiar indistintamente a todos mis vasallos, según el mérito de cada uno, i emplearlos como juzgase más conveniente, declaro, i mando que en adelante cessen en Mallorca $(b, 2)$ las costumbres y leyes que hablan de estrangería." Ibidem, Book III, Tit. 2nd, Auto XV, chap. 7, vol. IV, p. 303. It is noted that the term vasallo (vassal) is used in general with the sense of súbdito (subject).

54

"40. Han de cessar las prohibiciones de $(I, 5$. estrangería, porque mi Real intención es que en mis Reinos las dignidades, i honores se confieran $(m, 5$.$) reciprocamente a mis vasallos por el$ mérito, i no por el nacimiento, en una, ú otra Provincia de ellos." Ibidem, Book III, Tit. 2nd, Auto XVI, chap. 40, vol. IV, p. 308.

55

Ibidem, Book III, Tit. 2nd, Auto XXII, Resolution, p. 313.

56

"En la opción de plazas, i piezas Eclesiásticas los Aragoneses, Valencianos, i Catalanes sean iguales a los Castellanos, dexando a los Mallorquines en possesion de sus fueros, i rentas Eclesiásticas, q gozan por Cedulas Reales, i Bulas Pontificias". Ibidem, Book III, Tit. 2nd, Auto XXX, pp. 321-322.

57

HERZOG, Tamar, Vecinos y extranjeros..., pp. 145-147.

58

HERZOG, Tamar, "Los americanos... op. cit. pp. 78-92.

59

CHIARAMONTE, José Carlos, "Modificaciones del Pacto Imperial", in ANNINO, A., CASTRO LEIVA, L. and GUERRA, F. X., De los Imperios a las Naciones: Iberoamérica. Zaragoza: iberCaja, 1994, pp. 107-128.

60

CHIARAMONTE, José Carlos, op. cit., in ANNINO

A., CASTRO LEIVA, L. and GUERRA, F.X., op. cit., p. 112 and note 14, about the City of Mexico requesting a Court vote.

61

The 1805 Novísima recopilación de las Leyes de España records the Bourbon centralizing innovations, already incorporated in the 1775 Nueva Recopilación re-edition. As the subtitle makes clear, it is a reform of Philip IV's 1567 Recopilación, reprinted in 1775, which incorporates the Royal pragmáticas, decrees, orders and resolutions, and other providences which were not compiled and issued until 1804.

62

HALPERIN DONGHI, T., Reforma y disolución de los imperios ibéricos, / 1750-1850, Madrid: Alianza, 1985, p. 60.
Foreigners who wished to obtain naturaleza in some of the American kingdoms in the 18th century, with a view to settling down and trading, had to obtain it by negotiation with the Royal power, even if naturaleza by integration (i.e., temporary residence which could be extended by composition) was rather common at the time. In America, it was more difficult for foreigners to obtain naturalized status than in the Peninsula, as well as the accompanying privileges, since while in Castile naturalization achievement was directed to position and office achievement, in the Indies it was directed to participation in transatlantic trade, and its refusal was also linked to domestic market protection. Those naturalized Spanish were not easily recognized as naturales in America and vice versa, without the matter being addressed in law, only reflected in legal and social practices.

In turn, those naturales from the Indies were discontent when after the Bourbon reforms they were progressively excluded from the provision of American placements, offices and benefits. ${ }^{58}$ There was what José Carlos Chiaramonte described as 'the clash between the monarchy's centralizing tendencies and their subjects' autonomist tendencies. ${ }^{19}$ For this historian, the decentralizing tendencies recorded during the late Hapsburg period, with a weakening of Crown control over taxes, military resources and justice in favour of local administration, facilitated the Castilian bureaucracy becoming a mediating instance between the king and his subjects rather than an instrument of Royal absolutism. This persistence of a medieval and modern self-governing town tradition reflected in the Courts meetings continued in the 18th century both in Spain and in America. But, if Spain tends to weaken with support from Royal bureaucracy and the Church, in America Bourbon reforms created discontent. American subjects, as supposed by the Indies legislation, felt they were members of the Castile crown, together with other peninsular kingdoms; and on those grounds they based demands ${ }^{60}$ and selfgovernment practices. The Bourbon administration tendency was to ignore those suppositions and refer to American territories as colonies, as well as limiting the power of municipalities in American kingdoms, counterbalanced by viceroys, audiencias (courts), governors. However, the sale of offices, as it left the main positions in town governments in the hands of local oligarchies, facilitated the continued self-government tendencies. But the Bourbons advanced over municipality powers on the topic of fiscal control, and over the administration uniformity at both sides of the Atlantic. ${ }^{61}$ Administrative and fiscal reforms were a great factor in the American reaction, as they upset the local elites' interests, displaced by peninsular elites. ${ }^{62}$

Tamar Herzog contextualizes the criollista (pro-creole) speech, apart from a pretended nationalist content. In the beginning, American vindications were based on service and genealogy issues. By the end of the 16th century, some would already state their rights on the grounds of their American birth using the concept of naturaleza. Until then, criollos (the Spanish-American creole) claimed both an American and a peninsular naturaleza. In the 18th century, criollos and peninsulars competed by mutual exclusion; since then an identity of confrontation with the Europeans can be observed.63

In 1667, Pedro de Bolívar y de la Redonda had already disqualified Spaniards, stating that they loved Spain more than Spanish America, since they regarded it as a foreign land and kept their loyalty to their original peninsular community, where their families resided and where they wished to return. However, according to Spanish laws unrepealed by the Bourbons, 
HERZOG, Tamar, "Los americanos...", op. cit., pp. 78-79.

64

HERNANDEZ DAVALOS, J. E (ed), "Representación que hizo la ciudad de México al rey don Carlos III en 1771 sobre que los criollos deben ser preferidos a los europeos en la distribución de empleos y beneficios de estos reinos", March 2nd, 1711, in Colección de documentos para la historia de la guerra de independencia de México de 1808 a 1821, México, J. M. Sandoval, 1877, t. 1, num. 195, pp. 427-455, especially 429-430, apud HERZOG, T. "Los americanos...", pp. 84-85 and note 36 .

65

FÉLIX BLANCO, J. (ed), Documentos para la vida pública del libertador, Caracas, "La Opinión Nacional" printing press, 1875, pp. 269-270, apud T. HERZOG, "Los americanos...", op. cit., p. 85 and note 38 .

66

HERZOG, T., "Los americanos...", op. cit. p. 85 and note 39 .

67

La Constitución de Cádiz (1812) y discurso preliminar a la Constitución, edited by FERNÁNDEZ GARCÍA, A., Madrid: Clásicos Castalia, 2002, p. 89; hereinafter Constitución de Cádiz (Cadiz Constitution).

VARELA SUANZES-CARPEGNA, J. La teoría del Estado pp. 208 and 237.

69

DSCGE Ses. Sept. 3rd, 1811, No. 336, p. 1754.

70

DSCGE Ses. Sept. 6th, 1811. No. 339, p. 1788.

71

See GIL PUJOL, F. X. "Un rey, una fe, muchas naciones. Patria y nación en la España de los siglos XVI-XVII". In ÁLVAREZ-OSSORIO ALVARIÑO, A., and GARCÍA GARCÍA, B. J., La Monarquía, op. cit., p. 52.
Spanish and Americans - the latter, as members of the Castilian kingdoms - formed a single community: that of the Spanish kingdoms naturales. The Spanish historical constitution would change in the 18th century with the imposition of Castilian public law to the kingdom of Aragon and the annulment of office reserves in each kingdom by the Bourbons. But the changes affected the Peninsula more than America. Nevertheless, in the latter, tension between Spaniards and Americans is manifest, for instance, in the 1771 Mexico cabildo (town council), when its members declared that the equality imposed by positive law could not be upheld by natural law, since 'among natural effects there is, and very rightly, the love that men have for the land where they were born and the lack of affection for any other, being these two motives the most solid principles which persuade towards posting a natural and resist posting a foreigner. ${ }^{\prime 64}$ The Caracas cabildo insisted in 1796 on the natural foreignness of peninsulars, stating that in them it was possible to note the 'natural weakness with which a man regards others' interests and those of a country where he is only in passing, and where he arrived only led by the wish to acquire enough assets to end his career in his own country or elsewhere...65, an opinion shared by Servando Teresa de Mier. ${ }^{66}$

Naturaleza and citizenship in the Twelfth-Year Courts deliberations As established in Article 1, Chapter I, Title I of the Spanish 1812 Cadiz Constitution, 'the Spanish Nation is the reunion of all the Spanish from both hemispheres' ${ }^{\prime 67}$, deliberations on citizenship and proposals on the representation of Nation posited at the Courts sessions between September 3rd and 27th, 1811 display the opposing stances around the issue of defining the citizen. The article text implies a separation from dualist, organicist and corporate positions of Royalist deputies, and a definition of Nation as the sum of its composing individuals, based on the dogma of popular sovereignty. ${ }^{68}$ But that does not mean that old references were completely abandoned. In debates, traditional historicist and corporate positions on naturaleza and vecindad alternate with new, contemporary terms of French and English connotations, which become sharper around political rights of the castas (castes) and political participation with active and passive citizenship.

Some traditionalist deputies, attached to a historicist lexicon, as the peninsular F. Gutiérrez de la Huerta, link naturaleza and citizenship. Naturaleza would be a quality 'of those who, having been born, raised and educated in the kingdom, acquired its customs, uses and concerns as their mother's milk, and took on that exquisite and particular sensibility for homeland affairs which is at the base of the character of nations who have it as their own, and true safeguard of their freedom and independence.'69

Central American Larrazábal does likewise clearly when he recalls the concept of naturaleza according to Alphonse X's Partidas, applying it to the right of citizenship by the castes, with a broad conception that could not manage to survive debate:

'... naturaleza refers to the debt that a man has for a right cause to love each other; and if this naturaleza is achieved just by being born in the Kingdom from parents who are native in it, it is clearly the competence of those castes the right to nativeness, and being the right to citizenship part of it, it cannot be disputed. ${ }^{70}$ On the same grounds, medieval annotators held the impossibility of a change of naturaleza, later gradually accepted.11 
72

DSCGE Ses. Sept. 3rd, 1811, No 336, p. 1754. Discussion of Art. 19.

73

Ibidem.

74

DSCGE Ses. Sept. 4th, 1811, No. 337, p. 1760.

Diverse non-automatic forms of access to vecindad are often recorded in peninsular municipal ordinances, whose features are referred to in this debate, showing the connection established by many deputies between achievement of vecindad and naturaleza, and conditions for citizenship.

75

HERZOG, T. Vecinos y extranjeros..., p. 209.

76

Ibidem, p. 1762

77

DSCGE Ses. Sept. 3rd, 1811, No. 336, p. 1754. Constitución de Cádiz, Tit. II, Chap. IV "De los ciudadanos españoles", art. 19, p. 95.
The 1565 pragmática defined as naturales those who descended from a father and a mother who were native to the kingdom, although it accepted ascendency on either line otherwise. The cited Deputy Gutiérrez de la Huerta, who confesses to being unable to come to an agreement with his fellow deputies, likewise identifies cartas de naturaleza (nativeness certificates) and cartas de ciudadanía (citizenship certificates): '... Courts will be able to concede a special citizenship certificate to that foreigner who already enjoys the rights of a Spaniard (i.e. according to the articles 2 and 3 , chapter II of the preceding title), to whom has already obtained from the same a nativeness certificate, or to whom, without it, has ten years of vecindad, earned according to law in any town in the Monarchy.72

In his opinion, 'the law of Spain and the law of the Indies are confused', in that they differ as to the prior residence time requisite (ten years for the former and twenty for the latter, as well as settlement and marriage), an exigency already present in the pragmática.

His concern originates in the fact that '... experience has shown the difficulty with which affection for the native country is dispelled, and its interests postponed, even when they are unfair, and the residence country favoured instead', which is why he wishes 'for us to be cautious and prudent in opening our gates to foreigners to participate in honours, offices and graces which form... the heritage of real Spaniards. ${ }^{13}$

The reserve of corporate-origin offices appears once more in the uneasiness of a deputy who cannot conceive of the Spanish nation as the whole of abstract Spaniards and reputes as 'true Spaniards' those who were born, raised and educated in the kingdom, though in either hemisphere, which does not mean that for him they are interchangeable, as they were not for Simón Bolivar either, or for most of the American deputies.

In other cases, there are doubts on the connection between the categories of vecino and citizen. For example, Deputy Bahamonde during debate of article 21 wondered whether the son of a family (son of a vecino) achieves citizen status just by being twenty-one years old, even if he is not emancipated or out of parental authority (i.e., living autonomously). In that case, would be he a vecino or a resident? The problem is that, if he was not a vecino, he should not enjoy the quality of citizen. ${ }^{74}$ The casuistry of naturaleza and vecindad in pre-constitutional culture makes these difficult to translate into constitutional terms. Deputies to the Twelfth-Year Courts did not theorize the figure of the citizen as an abstract individual participating in an abstract nation -in spite of the cited article- but as real persons integrating concrete communities. ${ }^{75}$ The matter is defined somewhat differently in America, where according to the New Spain Deputy Guridi y Alcocer, '... the name of town (vecindad) right has been ignored, using the words citizen and vecino promiscuously.' Still this is a superficial difference, since 'natural and foreigner are the words found in our laws, and "carta de naturaleza" (nativeness certificate) is the name of the privilege accorded to strangers (foreigners), equivalent to the town right in other countries ${ }^{176}$, a parallel equated to natural and vecino.

During treatment of art. 1977, Gutiérrez de la Huerta had expressed his objections to the Courts' ability to grant a special citizenship certificate to a foreigner who already enjoyed the rights of a Spaniard (active citizenship), to the one who had obtained from them carta de naturaleza, or to the one who, without it, had ten years of vecindad, achieved according to law in any town in the Monarchy. In his view, the Spanish law 
78

Constitución de Cádiz, Tit. II, Chap. IV "De los ciudadanos españoles", art. 20, p. 96. Conditions for granting the certificate to a foreigner are: necessary marriage with a Spanish woman, having brought or settled in Spain some appreciable invention or industry, or having acquired real estate for which direct contributions were paid, or having settled in trade with his own and considerable (according to the Courts) capital, or having provided significant services for the Nation welfare and defense. By art. 21 p. 96, direct access to citizenship is granted to legitimate children of foreigners who reside and were born in Spain, who have never travelled abroad without a Government licence, and who after being twentyone years old have become vecinos, practising a useful industry, profession, or trade.

79

DSCGE Ses. Sept. 3rd, 1811, No. 336, p. 1754.

80

DSCGE Ses. Sept. 3rd, 1811, No. 336, p. 1755. is confused with the Indies law as to the time requisite, since different periods are required, besides settlement -'they have always considered the laws as the least equivocal grounds to presume in the foreigner the intention to remain, fidelity and adherence to national interests'- and marriage in the first ten years in the former: 'Without this security [settlement], founded on the knowledge of intimate respect that links man with stable property, and force him to defend the safety of his place of existence, it would be impolitic to enable foreigners to enjoy public office and give them part of the administration of the State...' To him, it is 'more important that to have brought or fixed in Spain some invention or appreciable industry' -since there is no rule to assess appreciability-, 'especially noting that industry, due to its natural immobility, forms with the country where it is settled only temporal and unextendable links beyond the security needed for its exercise and free disposal of the fruit of its labour', an argument that identifies him with the French physiocrats. Both requisites are compiled in art. $20^{78}$.

Contrary from what happens in America, in Spain a foreigner cannot settle down to achieve vecindad in a town within ten leagues of the land frontier. Gutiérrez de la Huerta estimates that, when granting cartas de naturaleza, it is necessary to bear in mind the peninsular frontier security, preserve peace in the American dominions hindering foreigner participation and 'economize as much as possible those participation graces in trade with those possessions in favour of true naturales', with a view to reconciling 'the acquisition of useful vassals from outside with the happiness of those from the inside, and State security ${ }^{179}$, coinciding with his prior arguments. The carta de naturaleza granted for the Peninsula and that for Overseas are different in character, since in the former category there are four types, extended for several graces and authorizations, and only one of the latter, to trade in America and not for municipal positions, as noted in art. 23.

Gutiérrez de la Huerta considers that participation in authority distinctions, public office, benefits, and honours constitute 'exclusive heritage of true naturales of the Kingdom' -as detailed above-, 'due to reciprocity, justice and [political] convenience motives on which they are supported.'80 In his argumentation, it is possible to see the non-abstract corporate conception of citizenship, as far as it communicates to the latter the features of naturaleza, confirming differences between Spaniards and Spanish citizens, who for Huerta would be the only true naturales and, therefore, the only Spanish citizens.

The Cadiz Constitution would recognize a broad version of civil and human rights to Spaniards of both hemispheres. American Deputy J. Fernández de Leiva believed that the intention within the commission in which he was part '... was to consider as citizens those who descended on both lines from naturales from the Peninsula, America, Asia and other Spanish States, excluding those with even remote origins in foreign African countries.' Fernández de Leiva uses the terms citizens and naturales almost as synonyms: the children of naturales will be citizens in the future. He clarifies that in the commission there were contrary opinions to the African descendants exclusion, his own among them; he argues for '... declaring citizens those innocents born in Spain, in spite of their African origins, with the condition of having settlement or useful industry with which they could support themselves honestly, believing that this degree of civil 
81

DSCGE Ses. Sept. 3rd, 1811, No. 336, p. 1753. Art. 18.

82

ROSANVALLON, P. La consagración del ciudadano. Historia del sufragio universal en Francia. México: Instituto Mora, 1999, p. 113.

83

DSCGE Ses. Sept. 10th, 1811, No. 343, p. 1808. PORTILLO VALDES, J. M., "La revolución constitucional en el mundo hispano", in CLAVERO, B., PORTILLO, J. M., LORENTE, M. Pueblos, Nación, Constitución (en torno a 1812), Ikunager Ediciones, Vitoria, 2004. Avecindamiento (becoming vecino) and freedom excluded great groups of individuals from their rights.

84

SERRERA, R. M. "Sociedad Estamental y Sistema Colonial", A. ANINNO, L. CASTRO LEIVA, F.-X. GUERRA, De los Imperios..., op. cit. pp. 45-74, especially p. 67.

85

Constitución de Cádiz, Tit I, Chap. II "De los españoles", art. 5, pp. 90-91.

86

Ibidem.

87

ROSANVALLON, Pierre. La consagración, op. cit., p. 96.

88

DSCGE Ses. Sept. 3rd, 1811, No. 336, p. 1753. His arguments are aimed at contradicting Garcia Herreros, who in the same session advocated for suppression of art. 19 since, in his view, whoever had carta de ciudadania should enjoy citizenship rights.

89

Constitución de Cádiz, Tit. II, Chap. IV "De los ciudadanos españoles", art. 18, p. 95. Ses. Sept. 3rd, 1811, No. 336, p. 1753.

90

Constitución de Cádiz, Tit. II, Chap. IV "De los ciudadanos españoles", art. 22, p. 96. They are recognized as Spaniards, but not as Spanish citizens, a condition they would access by 'virtue' and 'worthiness.' The Courts '... will grant carta de ciudadano to those who do the Homeland qualified service, or to those who are distinguished by their talent, application and conduct, under condition that they are descended from a legitimate marriage of innocent parents; that they are married to an innocent woman, that they are vecinos in the Spanish dominions, and that they practise a useful profession, trade or industry with their own capital. existence which places them in the category of good men and the general common plain status, far from disturbing the public order, is very fair and politically convenient.' 81

In this text, the issue of slavery and 18th-century anthropological conceptions about Africans can be noted, which will be manifest in long debates where confronting arguments would be expanded with ideas on settlement and useful industry which allow the individual an autonomous existence. ${ }^{82}$

But how does Leiva define the origin of citizens? By the ius sanguini and the ius soli, as well as 'the degree of civil existence', which he recognizes in African descendants, but other deputies refute. Deputy Creus founds his opposition to granting citizen rights to the castes 'not because they come from Africa, but because they come from an irreligious, immoral Nation, almost denaturalized by reason of its customs', and because their parents' influence of their habits does not stop. ${ }^{83}$ The castes, as far as the African descendants are concerned, remain outside the legal system in the colonial world, even in the case of free individuals, but in the Cadiz Constitution $^{84}$ they are acknowledged as Spaniards if they have been freed.

As we have mentioned, the Twelfth-Year Constitution distinguishes two stages in citizenship: Spaniards ${ }^{85}$ and Spanish citizens. Spaniards are defined in Art. 5. There, besides defining Spaniards as all free men who were born and are vecinos in the Spanish dominions, as well as their children ${ }^{86}$, there is also recognition as such for those foreigners who have obtained carta de naturaleza, those who have been vecinos for ten years in any town in the monarchy and those freed men who were set free in Spain. Among their obligations, there is: loving the homeland, obeying the Constitution and laws, respecting established authorities, paying taxes and defending the homeland when they are drafted by law. In the article, different criteria for definition are combined: freedom, ius sanguini, ius soli, settlement. These members of the nation are limited to active vote as far as their political participation rights; i.e., they can elect, but not be elected. To Gutiérrez de la Huerta's historicist arguments about differences between Overseas and Peninsular cartas de naturaleza, Argüelles will respond that, despite always preserving the formula of cities requesting consent for Courts voting in order to naturalize foreigners, former governments usurped all these faculties and acted arbitrarily in their grants. But he stresses that 'The citizen... has very different and broader rights than the simple Spaniard', recalling passive vote, which citizens enjoy exclusively. The reasons why a Spanish citizen can lose this quality, or be suspended in the exercise of his rights, are already present in the 1791 French constitu$\operatorname{tion}^{87}:$ :... he who is not of competent age, who is prosecuted, who is a native from Africa, who is in another's pay, etc., even if he is a Spaniard, has no right to exert this citizen acts until the time indicated in other articles is passed.' ${ }^{88}$ The aim is to limit citizenship to those who have autonomy.

At last, the article was worded as follows: 'Citizens are those Spaniards who, on both ascendant lines, have their origin in the Spanish dominions of both hemispheres, and are vecinos in any town of the said dominions.'89 (Art. 18).

Again, the avecindamiento (becoming a vecino) issue recalls corporate conceptions related to vecindad. Another issue that gave rise to heated discussion was art. $22^{90}$ : concession of citizenship to castes, composed of free individuals, born of Spanish parents on Spanish dominions of both hemispheres. The aim was to stop African descendants, as well as those of 
91

Constitución de Cádiz, Tit. II, Chap. IV "De los ciudadanos españoles", art. 23, p. 97. It establishes that only those who are citizens will be able to obtain municipal positions or office and elect for them in the cases prescribed by law.

92

Constitución de Cádiz, Tit. III, "De las Cortes", Chap. I "Del modo de formarse las Cortes", art. 29, p. 99. It establishes that the base for the computation will be the population made up of those naturales who are native on both ascendant sides from Spanish dominions, and those who have obtained a carta de ciudadania from the Courts, as well as those mentioned in art. 21

93

Constitución de Cádiz, Tit. III, Chap. I, art. 28, p. 99. It establishes that the demographic base for national representation would be the same for both hemispheres.

94

Constitución de Cádiz, Tit III, Chap. I, art. 31, p. 100 establishes that, for every seventy thousand souls in the population, computed as dictated in art. 29, there will be one deputy to Courts.

95

DSCGE Ses. Sept. 4th, 1811, No. 337, p. 1762.

96

DSCGE Ses. Sept. 4th, 1811, No. 337, pp. 1761-1762.

97

DSCGE Ses. Sept. 4th, 1811, N. 337, p. 1766.
Spanish, Creole and Indian origin mixed with them, from having access to citizenship and, consequently, to public positions and office, as dictated by art. 23. ${ }^{91}$ Article 29, Title III, Chapter $1{ }^{92}$ excluded castes from the population computation on which, according to Arts. $28^{93}$ and $31^{94}$, the number of deputies for each electoral district would be assigned; an exclusion resulting in a reduction in the number of American representatives.

In the art. 22 debate, American deputies upheld an idea of Nation composed of all the individuals who were part of it. Thus, Alcocer, while arguing that art. 22 contradicts art. 21 as far as it denies the castes Spanish citizenship, finds support in the authority of the Partidas: 'Naturaleza, though obtained in different forms, is first and best obtained by being born in the land, as quoted in Law 2, Title XII, Partida 4. Reason confirms this, since birth should be preferred to origin... What motive will there be to deny the quality of citizen to those who have been born in Spanish territory due to their African origin? ${ }^{95}$

Of a like mind was Deputy Uria, who argues that, passed with that wording, the article discredits the Constitution, since if the Nation is sovereign and if those who are not estimated as citizens are recognized as part of it, the latter are disrespected by pretending to deprive them of rights which they are part of and which are owed to them by the Spanish society.

American deputies expressed an idea of Nation composed of all and every one of its individual members; i.e. sovereignty was not owned by the Nation as a single subject, as a corporation according to the view of some Spanish deputies, but it fell to all and every one of the individuals that composed it as a natural right. Therefore, each of them held a corresponding part of that faculty. That is, they upheld the dogma of people's sovereignty. 'The greatest splendour of men in Spain is to have been born free in its precious territories, and be a vecino in them; that is, to be Spanish, needing no other circumstance to be so, and without their origin, whichever it may be, can deprive them of this quality, the most appreciable and decorous: ... To be a part of national sovereignty and not a citizen of the Nation without personal demerit are two inconceivable things, and they negate one another. Origin by itself cannot so imperiously influence that numerous portion of the Spanish, who, respecting the substantial part of sovereignty that corresponds to them, deprives them of what is only accessory and accidental. Such is, in my view, the title of citizen. ${ }^{196}$ So declares Deputy Uría.

The whole argument leads to manifesting the contradiction between a corporate view of citizenship as a privilege (political rights discerned by the body possessed of sovereignty, i.e. the Courts) and the rational approach to it. Clergyman Gordoa points out contradictions in other articles. 'Because, how to understand, Sir, that those who come from Africa (...) are at the same time Spanish and non-Spanish, members and non-members of society, which they are also compose, and which is called Spanish Nation? Sovereignty is one and indivisible; this, as you have declared, resides esentially in the Spanish Nation, which by articles 1 and 6 is also composed of those who come from Africa, and by the same sovereignty resides in them, and still they are not Spanish citizens, without any other hindrance that their origin, i.e., that they are not Spaniards.97

Arispe holds that the October 15th decree, aimed at calling the census which should be the grounds for electing deputies, had only invited free men, without expressly calling up the castes, but not excluding them either. 'You ... 
98

DSCG Clergyman Gordoa, E. Ses. Sept. 5th, 1811, No. 338, p. 1774

99

VARELA SUANZES-CARPEGNA, J., op. cit., p. 238

100

DSCGE Ses. Sept. 7th, 1811. No. 340, p. 1799.

101

VARELA SUANZES-CARPEGNA, J., op. cit., p. 230-232.

\section{2}

Constitución de Cádiz, Tit. III, Chap. V, "De las Juntas electorales de provincia", art. 91, p. 110. 'In order to be a deputy at Courts it is necessary to be a citizen in full exercise of his rights, of twenty-five years of age, and born in the province, or a vecino in it with residence of no less than seven years, whether in lay estate or secular clergy; and the choice may be among those who make up the Junta, or those outside it:

\section{3}

Diario de la Sesiones y Actas de las Cortes, T. VIII, p. 459, apud VARELA SUANZES-CARPEGNA, J., op. cit., p. 231. have proclaimed that the Nation is a reunion of all the Spanish of both hemispheres, and that in them resides sovereignty essentially, as does the faculty to form its constitutional laws. If, then, castes are Spanish, they must participate in that sovereignty and legislative faculty: if they have that participation, they must practise it through their representatives; and, as they are unable to do this if they are not citizens, either they are Spanish and members of the citizenship, or they are owed justice, grounded on the same constitution, the right to citizenship, and it is not in accordance with the law to deny it to them. ${ }^{198}$ That is to say that most of the American deputies refuted the distinction that the liberal doctrine, upheld by most Spanish liberals, established between civil and political rights as a scholastic tradition legacy stating that the origin of power resides in the community. ${ }^{99}$ Peninsular liberal deputies attributed sovereignty to an indivisible, ideal subject, the Nation, who owns the exclusive right to determine who is part of the active or passive electorate, and not the individuals who compose it, because politics is not a natural right of the individual, prior to positive right, but a public function determined by the Nation through juridical ordering. So states Garcia Herreros from the perspective of the peninsular liberals, when he posits that in debate, natural and civil rights are confused with political rights: 'We call natural rights those which emerge from natural law; civil and political rights those which are issued from those laws, respectively...'100, estimating that political rights, as nonnatural rights, depend on the Courts' decisions, as far as they are sovereign.

On the other hand, they object to castes being part of the native community since they have presumably been brought against their will, due to slave trade.

Besides, many American deputies upheld an idea of corporate Nation of territorial leanings ${ }^{101}$, which could be seen concretely in the art. 91 debate of the constitutional draft. ${ }^{102}$ This article stated that, in order to be elected deputy at Courts, it was necessary to be a native to the province for which the candidate was proposed, or to be a vecino in it with a residence of no less than seven years, a condition which was contested by the former, as it opposed them to peninsulars settled in America with the same number of residence years in it. American Deputy Leiva argued that 'The fact that the congregation of deputies from towns which form a unique nation represent national sovereignty does not destroy the character of particular representation of their respective provinces. The deputy has two great obligations: one, to tend to the Nation public and general interest; second, to expose the means which can be adopted, without prejudice for the whole, for the welfare of his province.' For him, the Spanish Nation was a sum of provinces: 'The Galician representing Galicia, the Asturian, Asturias, the Peruvian, Peru, and likewise the rest of the provinces with due equality, we will manage to have a Spanish nation that is perfectly and naturally represented.'103

This interpretation was singularly different from that of the unity of general will of the Nation advocated by the liberal deputies from the peninsula.

\section{Conclusions}

Historiographical discussion in the last decades - with a basis on works by Tomás y Valiente, Garriga, Clavero, Tamar Herzog, among others - has helped strengthen a cultural and political analysis at the expense of some sociological interpretations which attributed to each estate a specific view on diverse problems regarding political citizenship and its place in society, granting history of law a more anthropological view, though not without its difficulties. 
Through examples taken from debates and the final draft of the cited constitutional articles, it is possible to appreciate the persistence of different forms of corporate conception of citizenship, belonging to the nature of subject and vecino, which show how difficult it was for deputies to break with the past. Some of these difficulties were not new, as observed when studying this issue in the light of the aggregative configuration of Hispanic monarchy, where each of the kingdoms kept its juridical-political identity between late 18th century and early 19th century, in the face of the Bourbon efforts to modify such situation. In spite of the aspiration to constitute a Nation of Spaniards who embraced broad population masses, old forms of inclusion and exclusion persisted among permanent members of the community (vecinos, naturales), which allowed for inclusion of the avecindados (Spanish, Creole, Indians who were native to the region) and non-avecindados (foreigners, travellers), but determined the exclusion of Africans and their descendants (arrived to their chagrin due to the slave trade), so objected by Americans. The decision in favour of a certain type of participation in the population census prior to the deputy election brought with it the significance in the numerical weight of American population, since Spanish representation ran the risk of being submerged during sessions under the number of Americans. Therefore, exclusions were also related to this fact; neither were all Americans in favour of caste representation. Despite this, American deputies retained a conception of corporate and territorial Nation which foresaw the exclusion from representation of peninsular Spanish avecindados in America.

\section{Bibliography}

ALBALADEJO, Pablo F. Fragmentos de Monarquía, Alianza, Madrid, 1992 ARTOLA, Miguel. (ed.) Las Cortes de Cádiz Marcial Pons, Ediciones de Historia, S.A., 2003, Constitucionalismo en la historia, Barcelona, Crítica, 2005. El modelo constitucional español del siglo XIX, Fundación Juan March, 1979. . La España de Fernando VII: la guerra de la Independencia y los orígenes del régimen constitucional, Espasa-Calpe, S.A., 1999. La Guerra de la Independencia. Madrid: Espasa Calpe, 2008. . Los Orígenes de la España contemporánea, 2 vols. Madrid: Centro

de Estudios Políticos y Constitucionales, 1959 (reed. 1975-1976). Nación y Estado en la España liberal, Madrid, Nóesis, 1994.

BARBA Jesús Marina. La reforma municipal de Carlos III en Ciudad Real (1766-1780). Chronica Nova 14, 1984-85.

CHIARAMONTE, José Carlos. Modificaciones del Pacto Imperial. In: ANNINO, A., CASTRO LEIVA, L Y GUERRA, F.X. De los Imperios a las Naciones: Iberoamérica. Zaragoza: IberCaja, 1994.

CLAVERO, Bartolomé. "Cádiz en España: signo constitucional, balance historiográfico, saldo ciudadano", en GARRIGA, Carlos y LORENTE, Marta, Cádiz, 1812. La Constitución jurisdiccional. Madrid: Centro de Estudios Constitucionales, 2007, p.447-526. "Para un concepto de revolución burguesa", Sistema. № 13 (1976). "Política de un problema: la Revolución burguesa", en CLAVERO, B. RUIZ TORRES P. y HERNÁNDEZ MONTALBÁN F. J., Estudios sobre la Revolución burguesa en España. Madrid: Siglo XXI, 1979. 

historia. Salamanca: Ediciones de la Universidad de Salamanca, 1993.

; PORTILLO, José M.; LORENTE, Marta, Pueblos, Nación, Constitución

(en torno a 1812). Ikusager ediciones S.A. y Fundación para la Libertad, Vitoria-Gasteiz, 2004.

COSTA. Pietro. Civitas. Storia della citadinanza in Europa. 1. Della civiltá comunale al settecento, Laterza: Bari, 1999.

Diario de Sesiones de las Cortes Generales y Extraordinarias. Biblioteca virtual Miguel de Cervantes, 2005, 4 tomos, 1811, Ses. del 4/09/1811, No 337.

DÍAZ PLAJA, Fernando. La Historia de España en sus documentos: El siglo XVII. Madrid: Instituto de Estudios Políticos.

DOMínGUEZ ORTIZ, Antonio. Carlos IIl y la España de la llustración. Madrid: Alianza, 1990 (1988). . Un intento de reforma municipal. In: Sociedad y Estado en el siglo XVIII español. Barcelona: Ariel, 1981.

FERNÁNDEZ ALBALADEJO, Pablo. Materia de España. Cultura política e identidad en la España moderna. Marcial Pons, Madrid, 2007. . Dinastía y comunidad política. El momento de la patria. In: FERNÁNDEZ ALBALADEJO, Pablo (ed.), Los Borbones..., Madrid: Marcial Pons-Casa de Velázquez, 2001. . Monarquía de los Borbones. In: Fragmentos de Monarquía. Madrid: Alianza, 1992.

. La Monarquía. Actas del Congreso Internacional "Carlos III y la Ilustración". Madrid, 1989, 3 vol. I.

FERNÁNDEZ SEBASTIÁN, Javier. Cádiz y el primer liberalismo español. Sinopsis historiográfica y reflexiones sobre el bicentenario. In: ALVAREZ JUNCO, José y MORENO LUZÓN, Javier. La Constitución de Cádiz: historiografía y conmemoración. Homenaje a Francisco Tomás y Valiente. Madrid: C. E. P. y C, 2006. Javier. España, monarquia y nación. Cuatro concepciones de la comunidad política española entre el Antiguo Régimen y la Revolución liberal. Studia Historica, Historia Contemporánea, vol. XII (1994).

FURET, François. Pensar la Revolución Francesa. Madrid: Petrel, 1980.

GARRIGA, Carlos. Orden jurídico y poder político en el Antiguo Régimen. In: GARRIGA Carlos y LORENTE Marta. Cádiz, 1812. La Constitución jurisdiccional. Madrid: Centro de Estudios Políticos y Constitucionales.

GIL PUJOL, F. X. Un rey, una fe, muchas naciones. Patria y nación en la España de los siglos XVI-XVII. In: ÁLVAREZ-OSSORIO ALVARIÑO, A, y GARCÍA GARCÍA, B. J. La Monarquía de las naciones. Patria, nación y naturaleza en la Monarquía de España. Madrid: Fundación Carlos de Amberes.

GÓMEZ MARTíNEZ, Alfredo. Cargos y oficios municipales en las ciudadres de León, Zamora y Salamanca durante el reinado de Carlos III. Estudios humanisticos. Historia, $\mathrm{N}^{\circ}$ 5, 2006.

GONZÁLEZ ALONSO, Benjamín. El régimen municipal y sus reformas en el siglo XVIII. Sobre el Estado y la Administración de la Corona de Castilla en el Antiguo Régimen. Madrid: Siglo XXI de España Editores, s.a., 1981.

HALPERIN DONGHI, T. Reforma y disolución de los imperios ibéricos, 1750-1850. Madrid: Alianza, 1985. 
HERZOG, Tamar. Los americanos frente a la Monarquía. El criollismo y la naturaleza española. In: ALVAREZ-OSSORIO ALVARIÑO, A y GARCÍA GARCÍA B. J. (eds.) La Monarquía de las naciones. Patria, nación y naturaleza en la Monarquía de España. Madrid: Fundación Carlos de Amberes.

Vecinos y extranjeros. Hacerse español en la Edad Moderna. Madrid: Alianza, 2006.

HESPANHA, Antonio Manuel. Visperas del Leviatán. Instituciones y poder político (Portugal, siglo XVII). Madrid: Taurus, 1989.

La Constitución de Cádiz (1812) y discurso preliminar a la Constitución, edición de FERNÁNDEZ GARCÍA A., Madrid: Clásicos Castalia, 2002

MARTÍNEZ SHAW, C, y ALFONSO MOLA, M. Felipe V. Madrid: Arlanza. 2001.

MATURANA, Antonio Calvo y GONZÁLEZ FUERTES, Manuel Amador, Monarquia, Nación y Guerra de Independencia: debe y haber historiográfico en torno a 1808. Cuadernos de Historia Moderna. Anejos, VII (2008).

Novísima Recopilación de las leyes de España Libro I Titulo XIV Ley VII. 1805.

Novísima Recopilación. Tomo Tercero, Libro IX, Tít. XXVII, San Lorenzo, 14/07/1620.

PASAMAR, Gonzalo. Medio siglo de historiografia: la escuela de los Annales en España. III Jornadas de Historia Moderna y Contemporánea (15-17 de sept. de 2004) UNdeINE, F. de H., Dep. de Historia, R. Argentina 2004 (CD).

PÉREZ LEDESMA Manuel. La invención de la ciudadanía moderna. In: PÉREZ LEDESMA, Manuel (dir.). De súbditos a ciudadanos. Una historia de la ciudadanía en España. Madrid: CEPC. 2007.

PORTILLO VALDES, J.M., "La revolución constitucional en el mundo hispano", en CLAVERO, B., PORTILLO, J.M., LORENTE, M., Pueblos, Nación, Constitución (en torno a 1812). Ikunager Ediciones, Vitoria, 2004. . Revolución de Nación. Orígenes de la cultura constitucional en España, 1780-1812, Madrid: CEPC, 2000. . "De la Monarquía Católica a la Nación de los Católicos", Historia y Política: Ideas, procesos y movimientos sociales, 17 (2007). Crisis Atlántica. Autonomía e Independencia en la crisis de la monarquía hispana. Madrid: Marcial Pons-Fundación Carolina, 2006.

ROSANVALLON, P. La consagración del ciudadano. Historia del sufragio universal en Francia. México: Instituto Mora,1999.

SUÁREZ, Federico. Las Cortes de Cádiz. Madrid: Rialp, 1982. . La crisis política del Antiguo Régimen en España (1800-1840). Madrid: Rialp, 1950.

TOMÁS Y VALIENTE, Francisco. Génesis de la Constitución de 1812. I. De muchas Leyes Fundamentales a una sola Constitución. Anuario de Historia del Derecho Español, T. LXV, 1995.

Tomo Tercero de Autos acordados, Madrid, 1745, Facsímil LEX NOVA, Valladolid, 1982.

VALLEJO Jesús. De sagrado arcano a constitución esencial. Identificación histórica del derecho patrio. In: FERNÁNDEZ ALBALADEJO Pablo. (ed.), Los Borbones. Dinastía y memoria de Nación en la España del siglo XVIII. Madrid: Marcial Pons-Casa de Velázquez, 2001.

VARELA SUANZES CARPEGNA, Joaquín. La teoría del Estado en las Cortes de Cádiz. Orígenes del constitucionalismo hispánico, 2ª edición, CEPC, Madrid, 2011.

VILAR, Pierre. Historia de España. Barcelona: Crítica, 2008. 